\title{
STUDI EMPIRIS FAKTOR-FAKTOR YANG MEMENGARUHI PERILAKU DISFUNGSIONAL AUDIT
}

\author{
Sarah Fitriani Istiqomah.P.P dan Rahmawati Hanny $\mathbf{Y}$ \\ Sekolah Tinggi Ilmu Ekonomi Y.A.I. Jakarta DAN Akademi Akuntansi YKPN Yogyakarta \\ Safitriani144@yahoo.co.id dan rahmahanny@gmail.com
}

\begin{abstract}
This study aims to examine and analyze the locus of control, turnover intention, time budget pressure, the performance auditor, leadership styles, organizational commitment to audit dysfunctional behavior. This type of research in this research is qualitative research. The population in this study is the auditors who work in public accounting firms throughout Jakarta. The sampling technique in this study were selected through purposive sampling technique. The number of samples in this study is $32 \mathrm{KAP}$ with 256 respondents. Analysis data are using regression analysis. The result of this research is the locus of control, turnover intention,time budget pressure, and performance have an influence on the behavior of dysfunctional audit. Leadership style and organizational commitment has no effect on audit dysfunctional behavior. And locus of control, turnover intention, time budget pressure, the performance auditor, leadership style and organizational commitment together have an influence on the behavior of dysfunctional audit.
\end{abstract}

Keywords: Locus of control, turnover intention, time budget pressure, the performance auditor, and dysfunctional audit

Abstrak. Penelitian ini bertujuan untuk menguji dan menganalisis locus of control, turnover intention, time budget pressure, kinerja auditor, gaya kepemimpinan, komitmen organisasi terhadap perilaku disfungsional audit. Jenis penelitian dalam penelitan ini adalah penelitan kualitatif. Populasi dalam penelitian ini adalah auditor yang bekerja di kantor akuntan publik seluruh Jakarta. Teknik pengambilan sampel dalam penelitian ini dipilih melalui teknik purposive sampling. Jumlah sampel dalam penelitian ini adalah 32 KAP dengan 256 responden. Analisis data menggunakan analisis regresi. Hasil penelitian ini adalah locus of control, turnover intention, time budget pressure, kinerja terhadap perilaku disfungsional audit. Sedangkan gaya kepemimpinan dan komitmen organisasi tidak mempunyai pengaruh terhadap perilaku disfungsional audit. Dan locus of control, turnover intention, time budget pressure, kinerja auditor, gaya kepemimpinan, dan komitmen organisasi secara bersama-sama mempunyai pengaruh terhadap perilaku disfungsional audit.

Kata kunci: Locus of control, turnover intention, time budget pressure, kinerja auditor, gaya kepemimpinan, komitmen organisasi.

\section{PENDAHULUAN}

Akuntan publik sebagai profesi yang memberikan jasa kepada masyarakat diwajibkan untuk memiliki pengetahuan dan keterampilan akuntansi serta kualitas pribadi yang memadai. Kualitas pribadi tersebut akan tercermin dari perilaku profesionalnya. 
Perilaku professional akuntan publik salah satunya diwujudkan dalam bentuk menghindari perilaku menyimpang dalam audit (dysfunctional audit behavior). Perilaku disfungsional yang dimaksud di sini adalah perilaku menyimpang yang dilakukan oleh seorang auditor dalam bentuk manipulasi, kecurangan ataupun penyimpangan terhadap standar audit. Perilaku merupakan perwujudan atau manifestasi karakteristik seseorang dalam menyesuaikan diri dengan lingkungannya. Perilaku ini bisa memengaruhi kualitas audit baik secara langsung maupun tidak langsung.

Perilaku yang mempunyai pengaruh langsung diantaranya adalah premature sign off atau penghentian prosedur audit secara dini, pemerolehan bukti yang kurang, pemrosesan yang kurang akurat, dan kesalahan dari tahapan-tahapan audit. Sementara perilaku yang mempunyai pengaruh tidak langsung terhadap kualitas audit adalah underreporting of time.

Perilaku-perilaku tersebut dapat berefek negatif terhadap hasil audit yang dilakukan auditor sehingga dikhawatirkan kualitas audit akan menurun. Menurunnya kualitas audit ini akan berdampak pada ketidakpuasan pengguna jasa audit terhadap keabsahan serta keyakinan akan kebenaran informasi yang terkandung dalam laporan keuangan auditan. Hal ini akan menyebabkan terkikisnya tingkat kepercayaan masyarakat terhadap profesi audit. Mengingat betapa berbahaya akibat yang dapat ditimbulkan oleh perilaku disfungsional yang dilaksanakan oleh auditor, maka akan sangat perlu untuk dikaji mengenai faktor-faktor apa saja yang dapat memengaruhi tingkat dysfunctional audit behavior, sehingga dapat diambil tindakan yang perlu demi menjaga kepercayaan masyarakat terhadap profesi audit dan kemajuan profesi.

Penerimaan penyimpangan perilaku diukur dengan bagaimana seorang auditor menerima beragam bentuk penyimpangan perilaku. Bentuk penyimpangan perilaku yang dilakukan oleh auditor meliputi: penyelesaian tugas audit tanpa melengkapi keseluruhan prosedur yang telah ditetapkan (Premature Sign-Off), menyelesaikan pekerjaan yang dibebankan dengan waktu pribadi auditor (Under Reporting of Time), dan mengurangi efektivitas pengumpulan bukti selama pengujian (Audit Quality Reduction Behavior/AQRB)

Berdasarkan penelitian Wahyudin (2011) menyatakan bahwa perilaku profesional auditor/akuntan publik salah satunya diwujudkan dalam bentuk menghindari perilaku menyimpang dalam audit (dysfunctional audit behavior). Berbagai penelitian menyatakan bahwa penyimpangan perilaku dalam penugasan telah menjadi permasalahan yang serius (Smith 1995, Otley dan Pierce 1995 dalam Wilopo, 2006).

Penelitian ini menggabungkan antara karakteristik internal auditor dan karakteristik eksternal luar pribadi auditor. Karakteristik internal auditor yang pertama adalah locus of control internal. Locus of control internal adalah tingkat keyakinan seseorang akan hasil tergantung pada karakter atau perilaku orang tersebut. Individu yang memilki locus of control internal cenderung lebih sukses dan memilki jabatan yang lebih tinggi dibanding individu yang memilki locus of control eksternal. Locus of control eksternal adalah sikap atau perilaku seseorang sangat tergantung pada kondisi luar dirinya (Wilopo, 2006)

Perilaku seseorang pada hakikatnya berasal dari dalam dirinya sendiri atau dari sisi internalnya (personal) dan faktor lingkungan atau faktor eksternal (situasional) yang mendukung seseorang dalam membuat suatu keputusan untuk melakukan suatu perbuatan. Sama halnya dengan perilaku akuntan publik atau auditor yang menurut Jansen dan Glinow (1985); Malone dan Roberts (1996) dalam Kartika dan Wijayanti (2007) 
menyimpulkan bahwa perilaku disfungsional auditor dapat disebabkan oleh faktor karakteristik internal dari auditor serta faktor eksternal saat melakukan proses audit.

Berdasarkan hasil penelitian Kartika dan Wijayanti (2007) adalah locus of control eksternal berpengaruh positif terhadap penerimaan perilaku disfungsional audit. locus of control eksternal berhubungan negatif terhadap kinerja karyawan. Locus of control sebagai anteseden hubungan kinerja karyawan penerimaan perilaku disfungsional audit. Auditor yang memiliki kecenderungan locus of control eksternal akan memiliki kinerja yang rendah dan auditor yang memiliki kinerja yang rendah akan lebih menerima perilaku disfungsional audit.

Penjelasan dari peneliti sebelumnya diatas memperkuat bahwa faktanya tidak semua kegiatan auditing berjalan mulus seperti teorinya, Banyak faktor yang memengaruhi seorang auditor untuk melakukan perilaku disfungsional. Untuk Semua KAP, perilaku disfungsional adalah hal yang harus ditekan dan diminimalisir seminimal mungkin. Tidak sedikit kasus yang sudah terungkap mengenai bangkrutnya suatu KAP akibat perilaku disfungsional, seperti skandal didalam negeri yaitu diambilnya tindakan oleh Majelis Kehormatan Ikatan Akuntan Indonesia (IAI) terhadap 10 Kantor Akuntan Publik yang diindikasikan melakukan pelanggaran berat saat mengaudit bank-bank yang dilikuidasi pada tahun 1998 (Winarto, 2002; Christiawan, 2003; Wibowo, 2010)

Setelah kasus Enron, yang merupakan kegagalan KAP Arthur Andersen, dan World.Com di Amerika Serikat pada 2001, serta kasus Kimia Farma, auditor dianggap ikut andil dalam memberikan informasi yang salah, sehingga banyak pihak mengalami kerugian materi dalam jumlah besar. Para auditor dianggap sebagai salah satu penyebab kegagalan recovery ekonomi global. Oleh karena itu, para praktisi dan peneliti di bidang auditing di seluruh dunia berusaha meningkatkan kinerjanya untuk mengembalikan kepercayaan masyarakat terhadap profesi auditor. Opini seorang auditor dapat menjadi salah akibat perilaku audit disfungsional yang menyebabkan kurangnya bukti audit prosedur.

Ada beberapa penelitian terdahulu memberikan opini tentang perilaku disfungsional audit. Turnover intention adalah berhenti atau keluar dari organisasi secara permanen baik sukarela seperti pensiun, atau tidak sukarela seperti pemecatan. Keinginan untuk keluar dari organisasi secara sukarela dapat bersifat fungsional dan disfungsional. Keinginan keluar dari organisasi yang bersifat fungsional, jika karyawan yang meninggalkan organisasi merupakan karyawan yang dianggap layak untuk keluar. Dalam penelitian Harini, Wahyudin, Anisykurlillah (2010) menunjukkan bahwa turnover intention tidak memiliki pengaruh yang signifikan terhadap perilaku penyimpangan auditor tetapi dalam penelitian yang dilakukan oleh Malone dan Robert (1996) menemukan bukti bahwa ada hubungan positif yang signifikan antara turnover intention dengan dysfunctional audit behavior karena menurunnya ketakutan akan kemungkinan jatuhnya sanksi apabila perilaku tersebut terdeteksi. Hal ini berarti bahwa seorang auditor yang memiliki keinginan untuk meninggalkan perusahaan lebih dapat terlibat dalam perilaku disfungsional yang disebabkan oleh penurunan tingkat ketakutan akan dijatuhkannya sebuah sanksi apabila perilaku disfungsional tersebut terdeteksi.

Perilaku disfungsional timbul karena adanya dilemma cost-quality. Cost yang besar diatur oleh waktu yang profesional, dan pengukuran yang tepat. Sebaliknya, kualitas tidak bias diukur dengan presisi yang sama namun penting untuk kesuksesan jangka panjang. Dilemma cost-quality disebabkan karena ketidakseimbangan antara fee audit yang diterima oleh auditor dengan kualitas audit yang diatur oleh standar profesional. Audit 
seharusnya ditetapkan dengan fee yang standar dan kualitas audit yang standar pula. Namun, auditor cenderung untuk tidak menetapkan fee audit sesuai standar. Fee audit yang rendah akan menyebabkan time budget menjadi singkat dan tidak diukur dengan akurat. Time budget yang rendah akan menurunkan kualitas audit. Time pressure menurut Herningsih (2001) adalah suatu keadaan ketika auditor dituntut untuk melakukan efisiensi terhadap anggaran waktu yang telah disusun. Time pressure terdiri dari dua dimensi yaitu time budget pressure dan time deadline pressure.Timbulnya time dealine pressure disebabkan oleh adanya kebutuhan untuk melengkapi tugas audit berdasarkan pedoman waktu tertentu, sedangkan munculnya time budget pressure disebabkan oleh adanya jumlah waktu yang telah dialokasikan dalam melengkapi tugas audit tertentu. Dalam penelitian ini peneliti menggunakan time budget pressure yang akan memengaruhi perilaku auditor dalam penugasan audit. Time budget pressure suatu audit mempunyai pengaruh positif terhadap perilaku disfungsional auditor (Otley \&Pierce, 1996). Semakin besar tingkat time budget pressure maka akan semakin besar pula kemungkinan auditor untuk melakukan audit quality reduction behaviour (AQRB), dan Under reporting of time (URT). Hasil ini didukung oleh penelitian yang dilakukan oleh Soobaroyen \& Chengabroyan (2005) bahwa time budget pressure suatu audit yang besar mempunyai pengaruh positif terhadap perilaku disfungsional auditor terdiri dari audit quality reduction behaviour (AQRB), premature sign-off (PSO) dan under reporting of time (URT) .

Kinerja berkaitan dengan hasil dari perilaku anggota organisasi di mana tujuan yang dicapai adalah dengan adanya tindakan atau perilaku. Kinerja melibatkan kegiatan manajerial seperti perencanaan, investigasi, koordinasi, supervisi, staffing, negosiasi dan representasi. Hal ini berarti bahwa seorang auditor dengan tingkat kinerja yang rendah lebih dapat terlibat dalam perilaku disfungsional karena peyimpangan perilaku disini dilihat sebagai kebutuhan dalam situasi dimana tujuan organisasi atau individual tidak dapat dicapai melalui langkah-langkah atau cara-cara umum yang sering dilakukan, tetapi menurut penelitian Hartati (2012) menyatakan bahwa kinerja memiliki pengaruh yang tidak signifikan terhadap perilaku disfungsional auditor. Penelitian Pujaningrum (2012) menyatakan bahwa kinerja memiliki pengaruh yang signifikan terhadap penerimaan dysfunctional audit behavior. Ada beberapa faktor lain yang berpengaruh terhadap perilaku menyimpang dalam audit selain mengenai turnover intention, time budget pressure, dan kinerja auditor yaitu locus of control, gaya kepemimpinan, dan komitmen organisasi.

Locus of control merupakan karakteristik personalitas yang menggambarkan tingkat keyakinan seseorang tentang sejauh mana mereka dapat mengendalikan faktor-faktor yang memengaruhi keberhasilan atau kegagalan yang dialaminya. Locus of control terkait dengan cara pandang seorang auditor mengenai suatu "keberhasilan" dan juga terkait dengan penggolongan individu menjadi dua kategori yaitu internal control dan eksternal control. Internal control merupakan individu yang percaya bahwa mereka memiliki kendali atas peristiwa yang terjadi pada dirinya. Sedangkan eksternal control merupakan individu-individu yang percaya bahwa suatu peristiwa dikendalikan oleh kekuatankekuatan dari luar seperti nasib, kemujuran dan peluang. Dalam konteks auditing manipulasi atau penipuan dilakukan dalam bentuk dysfunctional audit behavior. Perilaku ini adalah alat bagi auditor dalam upaya untuk mencapai tujuan kinerja individual serta untuk dapat bertahan dalam organisasi sehingga dapat memengaruhi tingkat turnover intention. Dengan demikian dapat dipahami bahwa locus of control eksternal berpengaruh langsung terhadap dysfunctional audit behavior serta kinerja dan turnover intention. 
Penelitian yang dilakukan oleh Irawati (2005) dan Pujaningrum (2012) menunjukkan bahwa locus of control berpengaruh terhadap perilaku menyimpang dalam audit dengan ditunjukkan bahwa semakin tinggi locus of control eksternal individu, semakin besar pula kemungkinan individu tersebut melakukan perilaku menyimpang. Sedangkan penelitian yang dilakukan oleh Wahyudin (2011) tidak terdapat pengaruh locus of control terhadap perilaku menyimpang dalam audit.

Komitmen organisasi merupakan sikap yang merefleksikan loyalitas karyawan pada organisasi dan berkelanjutan sehingga anggota organisasi dapat mengekspresikan perhatiannya terhadap organisasi dan keberhasilan serta kemajuan yang berkelanjutan (Luthans, 2006). Komitmen organisasional memiliki pengaruh yang tidak signifikan terhadap penerimaan dysfunctional audit behavior. Auditor yang berkomitmen tinggi akan mempunyai usaha yang keras dan akan mempunyai kinerja yang lebih baik daripada yang tidak berkomitmen. Komitmen yang tinggi, kurangnya kecenderungan bagi mereka untuk melakukan perilaku menyimpang dalam audit, sebaliknya tingkat komitmen terhadap organisasi telah menurun maka seorang auditor tidak lagi memperhatikan promosi dan kemajuan karirnya maka terdapat kemungkinan auditor akan melakukan pekerjaan tanpa kinerja yang memadai.

Perilaku disfungsional audit yang dapat memengaruhi kemampuan perusahaan akuntan publik untuk menghasilkan pendapatan, kualitas kerja yang lengkap dan profesional secara tepat waktu dan akurat untuk mengevaluasi kinerja karyawan. Memahami faktor yang berbeda terkait dengan perilaku ini akan membantu perusahaan audit dalam upaya mereka untuk menghalangi auditor terlibat dalam perilaku disfungsional audit. Hasil penelitian ini dapat memengaruhi prosedur audit, keputusan perekrutan, pelatihan dan promosi, dan membantu meminimalkan terjadinya dan penerimaan perilaku disfungsional audit.

Dengan demikian, mengidentifikasi faktor-faktor yang berkontribusi terhadap perilaku disfungsional audit, sikap auditor dianggap sebagai langkah pertama yang penting dalam memastikan ketika, mengapa dan bagaimana dari perilaku disfungsional audit yang sebenarnya. Menurut teori yang sudah berkembang dan berhubungan dengan anggaran penekanan, perilaku kepemimpinan dan efektivitas audit review untuk sikap auditor terhadap perilaku disfungsional audit seperti kurangnya rewiew dokumen, menerima penjelasan klien yang lemah, kegagalan untuk penelitian prinsip akuntansi, dan premature sign - off dari langkah audit yang diperlukan .

Penelitian ini berupaya mengembangkan dan meneliti kembali beberapa penelitian terdahulu yang menunjukkan hasil yang masih kontradiksi. Atau dengan kata lain, penelitian ini berusaha menguji kembali dengan mengkombinasikan beberapa variabel dari peneliti sebelumnya yang menunjukkan hasil saling kontradiksi terkait dengan berbagai faktor yang memengaruhi dysfunctional audit behavior yang meliputi locus of control, kinerja auditor, turnover intention, time budget pressure, gaya kepemimpinan, dan komitmen organisasi.

Berdasarkan uraian di atas, maka penelitian ini berusaha meneliti kembali secara empiris faktor-faktor yang memengaruhi perilaku disfungsional audit. Dengan demikian, tujuan penelitiannya adalah mengetahui dan menganalisis secara empiris faktor-faktor yang memengaruhi perilaku disfungsional audit yang meliputi locus of control, kinerja auditor, turnover intention, time budget pressure, gaya kepemimpinan, dan komitmen organisasi baik secara parsial maupun simultan. Adapun manfaat yang diharapkan dalam penelitian ini adalah bahwa selain dimaksudkan untuk pengembangan ilmu akuntansi 
khususnya auditing dan akuntansi keperilakuan, namun juga diharapkan memberikan manfaat praktis berupa masukan dan informasi yang layak dipertimbangkan dalam pengelolaan SDM (yaitu auditor) sehingga kualitas audit yang dihasilkan semakin meningkat dan optimal. Manfaat lain yang diharapkan adalah bahwa penelitian ini memberikan jalan untuk peneliti-peneliti berikutnya yang berminat untuk mengembangkannya lebih jauh.

\section{KAJIAN TEORI}

Perilaku Disfungsional Audit. Dalam setiap penugasannya seorang auditor selalu melibatkan perilaku, baik yang sesuai maupun menyimpang dari norma dan peraturan yang berlaku. Perilaku manusia dari segi biologis adalah tindakan atau aktivitas dari manusia itu sendiri yang mempunyai bentangan yang sangat luas seperti berjalan, berbicara, menangis, bekerja dan sebagainya. Robbins (2008) menjelaskan bahwa perilaku merupakan salah satu komponen sikap. Sikap (attitude) adalah pernyataan evaluatif, baik yang menyenangkan maupun yang tidak menyenangkan, terhadap objek, individu, atau peristiwa. Sikap mengandung tiga komponen yaitu: kesadaran, perasaan dan perilaku.

Perilaku juga berlaku dalam konteks audit dan sangat memengaruhi kualitas audit yang dihasilkan auditor dalam melaksanakan tugas pekerjaannya. Lestari (2010) menjelaskan bahwa untuk menghasilkan laporan audit yang berkualitas maka auditor harus melaksanakan beberapa prosedur audit yang merupakan serangkaian langkahlangkah yang harus dilaksanakan dalam melaksanakan audit. Dalam konteks auditing, manipulasi akan dilakukan dalam bentuk perilaku disfungsional. Berikut ini pengertian perilaku disfungsional menurut beberapa ahli adalah pengertian perilaku disfungsional auditor menurut Basuki dan Mahardani (2006), perilaku individu yang memiliki konflik dasar dengan tujuan organisasi.

Perilaku disfungsional merupakan tindakan-tindakan ketika seorang bawahan berusaha memanipulasi unsur-unsur dari sebuah sistem pengendalian yang ada demi kepentingan dirinya sendiri (Soobaroyen, 2006). Kelley dan Margheim (1990) menyatakan bahwa perilaku audit disfungsional adalah setiap tindakan yang dilakukan auditor dalam pelaksanaan program audit yang dapat mereduksi atau menurunkan kualitas audit secara langsung maupun tidak langsung. Perilaku penyimpangan audit adalah perilaku auditor dalam proses audit yang tidak sesuai dengan program audit yang telah ditetapkan atau menyimpang dari standar yang telah ditetapkan (Harini et al, 2010).

Dari pengertian - pengertian di atas, dapat disimpulkan bahwa setiap individu yang tergabung dalam suatu organisasi memiliki kepentingan atau tujuan tersendiri, baik tujuan yang sejalan maupun tidak dengan tujuan organisasi. Perilaku disfungsional ini adalah alat bagi auditor untuk memanipulasi proses audit dalam upaya mencapai tujuan kinerja individual yang dapat berpengaruh terhadap kualitas audit yang dihasilkan. Pengurangan kualitas audit yang dilakukan dari kegiatan ini mungkin dipandang sebagai pengorbanan bagi individu untuk bertahan dalam lingkungan audit (Lestari, 2010). Perilaku audit disfungsional adalah setiap tindakan yang dilakukan auditor selama pelaksanaan program audit yang dapat mereduksi kualitas audit baik secara langsung maupun tidak langsung (Kelley dan Margheim, 1990; Otley dan Pierce, 1996). Sikap auditor menerima perilaku disfungsional merupakan indikator perilaku disfungsional aktual. Dysfunctional Audit Behavior merupakan reaksi terhadap lingkungan dan dapat membahayakan kualitas audit, seperti underreporting of time. premature sign off, altering/ replacement of audit 
procedure Hal tersebut dipengaruhi oleh banyak faktor diantaranya sebagaimana terurai berikut ini:

Locus of Control. Locus of control adalah persepsi tentang kendali mereka atas nasib, kepercayaan diri dan kepercayaan mereka atas keberhasilan diri. Locus of control memainkan peranan penting dalam berbagai kasus, seperti perilaku disfungsional audit, job statisfaction, kinerja, komitmen organisasi dan turnover intention (Harini et al, 2010).

Teori locus of control menggolongkan individu apakah termasuk dalam locus of control internal atau eksternal. Pandangan hidup menurut internal dan eksternal locus of control sangat berbeda. Eksternal locus of control diidentifikasikan lebih banyak menyandarkan harapan untuk bergantung pada orang lain, hidup mereka cenderung dikendalikan oleh kekuatan di luar diri mereka sendiri (seperti keberuntungan), serta lebih banyak mencari dan memilih kondisi yang menguntungkan (Husna et al, 2012). Seseorang yang mempunyai internal locus of control yakin dapat mengendalikan tujuan mereka sendiri, memandang dunia sebagai sesuatu yang dapat diramalkan, dan perilaku individu turut berperan didalamnya. Individu dengan internal locus of control di identifikasikan lebih banyak menyandarkan harapannya pada diri sendiri dan juga lebih menyukai keahlian-keahlian dibanding hanya situasi yang menguntungkan. Jadi, internal locus of control dilaporkan memiliki kepuasan dan kesuksesan yang lebih tinggi dengan pekerjaannya serta terlihat lebih mampu menahan stress daripada locus of control eksternal.

Turnover Intention. Robbins (2006) mendefinisikan turnover sebagai pemberhentian karyawan yang bersifat permanen dari perusahaan baik yang dilakukan oleh karyawan sendiri (secara sukarela) yang disebut voluntary turnover maupun yang dilakukan oleh perusahaan yang disebut involuntary turnover. Turnover intention dapat didefinisikan sebagai keinginan seseorang untuk keluar dari perusahaan secara sukarela dari pekerjaanya. Turnover intention pada dasarnya adalah sama dengan keinginan berpindah karyawan dari satu tempat kerja ke tempat kerja lainnya. Istilah turnover intention masih dimaknai dalam tataran keinginan untuk berpindah dan belum sampai tahap realisasi berpindah ke tempat kerja lainnya. Banyak alasan yang menyebabkan timbulnya turnover intention diantaranya adalah keinginan untuk mendapatkan pekerjaan yang lebih baik. Indikasi terjadinya turnover intention adalah (1) absensi karyawan yang meningkat di dalam jam kerja, (2) penurunan rasa tanggung jawab karyawan dibandingkan sebelumnya, (3) peningkatan tindak pelanggaran tata tertib kerja, (4) peningkatan protes terhadap atasan atau kebijakan-kebijakan perusahaan terkait balas jasa atau aturan lain yang tidak sependapat dengan keinginan karyawan, (5) perilaku positif yang sangat berbeda dari biasanya, dan sebagainya.

Time Budget Presure. Auditor seringkali bekerja dalam keterbatasan waktu, untuk itu setiap KAP perlu membuat anggaran waktu dalam penugasan auditnya. Anggaran waktu dibutuhkan untuk menentukan kos audit dan mengukur kinerja auditor. Akan tetapi, seringkali anggaran waktu tidak sesuai dengan realisasi atas pekerjaan yang dilakukan, akibatnya muncul perilaku disfungsional yang menyebabkan kualitas audit lebih rendah. Saat menghadapi tekanan anggaran waktu, auditor akan memberikan respon dengan dua cara yaitu, fungsional dan disfungsional. Tipe fungsional adalah perilaku auditor untuk bekerja lebih baik dan menggunakan waktu sebaik-baiknya. Sedangkan, tipe disfungsional adalah perilaku auditor yang membuat penurunan kualitas audit. 
Anggaran waktu merupakan hal yang sangat penting bagi semua KAP karena menyediakan dasar untuk memperkirakan biaya audit, pengalokasian staf ke dalam pekerjaan audit, dan sebagai dasar untuk mengevaluasi kinerja auditor (Basuki et al, 2006). Tekanan anggaran waktu merupakan gambaran dan sistem pengendalian auditor. Tekanan anggaran waktu adalah keadaan yang menunjukkan auditor dituntut untuk melakukan efisiensi terhadap anggaran waktu yang telah disusun atau terdapat pembahasan waktu anggaran yang sangat ketat dan kaku (Sososutiksno, 2005). Anggaran waktu audit yang ketat dapat mengakibatkan auditor merasakan batasan waktu audit (time budget pressure) dalam pelaksanaan program audit akibat ketidakseimbangan antara time budget yang tersedia dan waktu yang dibutuhkan untuk menyelesaikan program audit (Kelley et al, 1990). DeZoort dan Lord (2012) menyebutkan ketika menghadapi batasan waktu atau time budget pressure, auditor akan memberikan respon dengan dua cara, yaitu fungsional dan disfungsional. Tipe fungsional adalah perilaku auditor untuk bekerja lebih baik dan menggunakan waktu sebaik-baiknya. Perilaku disfungsional dapat mengancam kualitas audit, diantaranya: penurunan tingkat pendeteksian dan penyelidikan aspek kualitatif salah saji, gagal meneliti prinsip akuntansi, melakukan review dokumen secara dangkal, menerima penjelasan klien secara lemah dan mengurangi pekerjaan pada salah satu langkah audit dibawah tingkat yang diterima Kelley et al (1990). Dalam hal auditor menanggulangi kendala time budget pressure dengan cara fungsional dilakukan melalui prosedur audit sebagaimana mestinya, tetapi memanipulasi catatan waktu dengan tidak melaporkan waktu aktual yang digunakan untuk pelaksanaan tugas audit atau tidak melakukan prosedur audit sebagaimana mestinya, tetapi auditor mengklaim bahwa mereka telah melakukan prosedur audit sebagaimana mestinya (Coram, 2003). Dengan demikian, keoptimisan auditor mengelola tekanan anggaran waktu akan mengantarkannya pada kesuksesan di masa datang dan kepesimisannya dapat menyebabkan timbulnya perilaku disfungsional.

Auditor yang menyelesaikan tugas melebihi waktu normal yang telah dianggarkan cenderung dinilai berkinerja buruk dan sulit mendapatkan promosi. Akhir-akhir ini tuntutan time pressure pada profesi auditor semakin besar (Lestari, 2010). Jadi tekanan anggaran waktu merupakan faktor yang memengaruhi kinerja auditor dan predikat KAPnya. Semakin auditor KAP mampu mengalokasikan waktu secara tepat, maka diyakini kos audit yang dianggarkan juga efisien sehingga auditor tersebut dapat menyelesaikan tugasnya dengan efektif dan efisien (Sososutiksno, 2005). Dan pada akhirnya akan memberikan kepuasan kepada klien dan disinyalir kualitas auditnya juga baik.

Kinerja Auditor. Kinerja yaitu hasil kerja secara kualitas dan kuantitas yang dicapai oleh seorang karyawan dalam melaksanakan tugasnya sesuai dengan tanggung jawab yang diberikan kepadanya (Mangkunegara, 2005). Sedangkan menurut Robbin (2006), kinerja merupakan hasil evaluasi terhadap pekerjaan yang dilakukan individu dibandingkan dengan kriteria yang telah ditetapkan bersama. Dengan demikian, kinerja merupakan konsep yang menunjukkan adanya kaitan output dengan input yang dibutuhkan seorang auditor untuk menyelesaikan tugas dan tanggung jawab auditnya. Pengukuran kinerjanya dilakukan dengan melihat jasa yang dihasilkan auditor dalam anggaran waktu tertentu yang telah ditetapkan. Seorang auditor dapat dikatakan produktif apabila ia mampu tugas dan tanggungjawab auditnya melebihi anggaran waktu dan biaya yang ditetapkan. Dan peningkatan kinerja auditor adalah dambaan setiap KAP, klien, dan publik, serta pihakpihak yang berkepentingan hasil audit yang dilakukan. Auditor sebagai seseorang yang memiliki kualifikasi tertentu dalam melakukan audit atas laporan keuangan dan kegiatan 
suatu organisasi untuk memperoleh dan mengevaluasi bukti secara obyektif mengenai pernyataan-pernyataan tentang kegiatan dan kejadian ekonomi, dengan tujuan menetapkan tingkat kesesuaian antara pernyataan-pernyataan tersebut dengan kriteria yang telah ditetapkan, serta penyampaian hasil-hasilnya kepada pemakai yang berkepentingan (Mulyadi, 1998). Kinerja auditor merupakan tindakan atau pelaksanaan tugas pemeriksaan yang telah diselesaikan oleh auditor dalam kurun waktu tertentu (Trisnaningsih, 2007). Dari pengertian tersebut, dapat disimpulkan bahwa kinerja auditor adalah suatu hasil karya yang dicapai oleh seseorang auditor dalam melaksanakan tugas-tugas yang dibebankan kepadanya yang didasarkan atas kecakapan, pengalaman, dan kesungguhan dalam mengelola waktu dan biaya dengan menjunjung tinggi nilai kualitas dan ketepatan waktu.

Gaya Kepemimpinan. Gaya kepemimpinan adalah pola perilaku konsisten yang diterapkan pimpinan kepada orang lain atau pola perilaku yang ditunjukkan pemimpin pada saat memengaruhi orang lain. Gaya kepemimpinan merupakan perilaku pemimpin dalam dua dimensi yaitu consideration dan initiating structure. Consideration adalah gaya kepemimpinan yang menggambarkan kedekatan hubungan antara bawahan dengan atasan, dimana muncul adanya saling percaya, kekeluargaan, saling menghargai, dan adanya komunikasi terbuka dan parsial antara pimpinan dan bawahan. Initiating structure adalah gaya kepemimpinan yang menunjukkan bahwa pemimpin mengorganisasikan dan mendefinisikan hubungan-hubungan di dalam kelompok, cenderung membangun pola dan saluran komunikasi yang jelas, dan menjelaskan cara-cara mengerjakan tugas yang benar. Pemimpin yang memiliki kecenderungan membentuk struktur yang tinggi, akan memfokuskan pada tujuan dan hasil. Hasil penelitian Otley dan Pierce (1996) yang menguji pengaruh gaya kepemimpinan terhadap perilaku disfungsional audit pada KAP menunjukkan bahwa gaya kepemimpinan struktur inisiatif cenderung mengurangi perilaku disfungsional audit.

Komitmen Organisasi. Komitmen organisasi merupakan ketertarikan dan kepercayaan terhadap tujuan dan nilai organisasi, kesediaan untuk berusaha sebaik mungkin demi kepentingan organisasi, dan keinginan untuk loyal menjadi anggota organisasi yang bersangkutan yang dinyatakan karyawan terhadap organisasinya. Komitmen terhadap organisasi artinya lebih dari sekedar keanggotaan formal, karena meliputi sikap menyukai organisasi dan kesediaan untuk mengusahakan tingkat upaya yang tinggi bagi kepentingan organisasi demi pencapaian tujuan. Komitmen tersebut ditunjukkan oleh kerja yang gigih (persistence) walaupun dibawah tekanan sekalipun. Individu yang mempunyai komitmen organisasi akan bekerja lebih baik daripada yang tidak berkomitmen. Tidak adanya komitmen organisasi berpengaruh tinggi terhadap perilaku disfungsional, seperti melakukan manipulasi atau kecurangan audit.

Komitmen organisasi adalah hasil kerja yang penting pada tingkat individu yang dihubungkan dengan hasil kerja lain, seperti absensi karyawan, usaha kerja (effort), dan kinerja. Komitmen organisasi mempunyai implikasi pada individu dan organisasi. Dari sudut pandang individu, komitmen seseorang terhadap organisasi membuat seseorang dapat memperoleh reward ekstrinsik seperti bonus dan award dan juga reward intrinsik seperti kepuasan kerja dan hubungan lebih baik dengan rekan kerja. Dari persepktif organisasi, komitmen karyawan yang tinggi akan mengurangi keterlambatan, tingkat ketidakhadiran (abseinteism) dan turnover, serta meningkatkan usaha, kualitas, dan kinerja karyawan. 
Kerangka Pemikiran dan Hipotesis. Pengaruh Locus of Control Terhadap Perilaku Disfungsional Audit. Locus of control memainkan peranan penting dalam kinerja dalam akuntansi seperti pada anggaran partisipatif. Locus of control juga memengaruhi dysfunctional audit behavior, job satisfaction, komitmen organisasi dan turnover intentions. Teori locus of control menggolongkan individu apakah termasuk dalam locus of control internal atau eksternal. Locus of control berperan dalam memotivasi sehingga locus of control yang berbeda juga mencerminkan motivasi yang berbeda dan kinerja yang berbeda. Individu dengan internal locus of control (internal) cenderung percaya bahwa tindakan mereka secara langsung berpengaruh terhadap outcome dan mampu melakukan kecurangan atau manipulasi untuk meraih tujuan pribadi. Dalam situasi dimana eksternal tidak mampu memperoleh dukungan yang dibutuhkan untuk bertahan, mereka memandang manipulasi sebagai strategi untuk bertahan (Solar dan Bruehl, 1971). Dalam konteks auditing, manipulasi atau kecurangan akan muncul dalam bentuk perilaku disfungsional. Perilaku tersebut dilakukan oleh auditor untuk memanipulasi proses audit dalam rangka meraih target kinerja individu auditor. Menurutnya kualitas audit yang diakibatkan perilaku tersebut dipandang auditor sebagai pengorbanan seperlunya agar dapat bertahan dalam lingkungan audit.

Sedangkan internal locus of control akan cenderung lebih sukses dalam karir mereka daripada eksternal locus of control, mereka cenderung mempunyai level kerja yang lebih tinggi, promosi yang lebih cepat, dan mendapatkan uang yang lebih dan dilaporkan memiliki kepuasan yang lebih tinggi dengan pekerjaan mereka serta terlihat lebih mampu menahan stress daripada eksternal (Husna, 2012). Dengan demikian, locus of control berpengaruh terhadap perilaku disfungsional audit (Chairunnisa et al, 2014; Hadi dan Nirwanasari, 2014; dan Pujaningrum, 2012).

Pengaruh Turnover Intention Terhadap Perilaku Disfungsional Audit. Turnover intention didefinisikan sebagai kemauan dengan kesadaran dan pertimbangan untuk meninggalkan organisasi. Pengujian mengenai turnover intention ini mendapatkan perhatian penting ketika penelitian-penelitian sebelumnya menyarankan bahwa variabel turnover intentions merupakan prediktor signifikan atas turnover aktual (Agustini, 2005). Turnover intention juga dipengaruhi oleh skill dan ability, dimana kurangnya kemampuan seseorang (auditor) bisa mengurangi keinginannya untuk meninggalkan organisasi. Job satisfaction telah ditemukan mempunyai hubungan terbaik dengan turnover intention. Karyawan dengan job satisfaction yang rendah akan cenderung keluar dari pekerjaan mereka dibandingkan dengan karyawan yang mempunyai job satisfaction yang tinggi. Jadi perilaku disfungsional audit dipengaruhi juga oleh turnover intention (Chairunnisa et al, 2014; Hadi dan Nirwanasari, 2014; dan Pujaningrum, 2012).

Pengaruh Time Budget Pressure Terhadap Perilaku Disfungsional Audit. Dalam kondisi normal, estimasi penyediaan jumlah waktu yang dialokasikan untuk suatu proses audit harus tersedia karena hal tersebut akan dijadikan dasar untuk estimasi biaya audit, alokasi pekerjaan dan evaluasi kinerja auditor. Keterbatasan dalam waktu yang telah ditetapkan dalam penugasan audit akan menyebabkan auditor bekerja di bawah tekanan waktu sehingga kemungkinan auditor mengabaikan beberapa proses audit dan hanya menyelesaikan yang penting-penting saja sehingga akan menghasilkan kinerja yang buruk dan memengaruhi juga hasil kerja audit. (Kartika, 2007). 
Tekanan anggaran waktu yang dihadapi oleh auditor profesional dalam bidang pengauditan dapat menimbulkan stress yang tinggi dan memengaruhi sikap, niat, dan perilaku auditor (Sososutikno, 2003). Para auditor cenderung untuk memilih berusaha keras untuk mencapai anggaran yang ditetapkan daripada memilih profesionalisme kerja ketika dihadapkan pada anggaran yang ketat dan sukar dicapai. Hal tersebut karena pentingnya pencapaian anggaran oleh seorang auditor sebagai evaluasi kinerja dalam melaksanakan tugasnya yang sangat berpengaruh terhadap karirnya. Auditor terkadang melakukan eksploitasi beragam penyimpangan perilaku untuk mencapai anggaran yang telah ditetapkan.

The Commission On Auditors' Responsibilities Report dalam Sososutikno (2003) membuktikan bahwa tekanan anggaran merupakan penyebab utama terjadinya penyimpangan perilaku seperti perilaku premature sign-off. Menurut Silaban (2009) Anggaran waktu audit yang ketat dapat mengakibatkan auditor merasakan tekanan dalam pelaksanaan prosedur audit karena ketidakseimbangan antara waktu yang tersedia dengan waktu yang dibutuhkan untuk menyelesaikan tugas audit, dan selanjutnya kondisi tersebut mendorong auditor melakukan tindakan audit disfungsional. Dengan demikian, time budget pressure mempunyai pengaruh terhadap perilaku disfungsional audit (Suprianto, 2009)

Pengaruh Kinerja Audit Terhadap Perilaku Disfungsional Audit. Tidak ada bukti meyakinkan mengenai hubungan antara kinerja dan perilaku disfungsional secara umum. Akan tetapi terdapat dukungan teoritis bahwa perilaku disfungsional lebih mungkin terjadi pada situasi ketika persepsi pribadi (self-perception) individu atas kinerjanya rendah. Adanya pandangan auditor bahwa evaluasi kinerja dan promosi karir dalam audit firm sangat erat berhubungan dengan kemampuan untuk menuntaskan penugasan audit sesuai dengan waktu dan anggaran yang ada menuntut auditor supaya dapat melengkapi semua penugasan dan prosedur audit sebagai dasar dalam memberikan opini mengenai kewajaran laporan keuangan. Para auditor cenderung untuk memilih berusaha keras untuk mencapai anggaran yang ditetapkan daripada memilih profesionalisme kerja ketika dihadapkan pada anggaran yang ketat dan sukar dicapai. Hal tersebut karena pentingnya pencapaian anggaran oleh auditor sebagai evaluasi kinerja dalam melaksanakan tugasnya yang sangat berpengaruh terhadap karirnya.

Dalam penelitian yang serupa, Solar dan Bruehl (1971) menyatakan bahwa individu yang tingkat kinerjanya berada dibawah harapan supervisor memiliki kemungkinan yang lebih besar terlibat dalam perilaku disfungsional karena menganggap dirinya tidak mempunyai kemampuan untuk bertahan dalam organisasi melalui usahanya sendiri. Jadi, perilaku disfungsional dipandang sebagai hal yang perlu karena tujuan individu maupun organisasi tidak dapat dicapai melalui tingkat kinerja tersebut. Oleh karena itu, auditor yang memiliki persepsi rendah atas kinerjanya diperkirakan menunjukan penerimaan atas perilaku disfungsional yang lebih tinggi. Jadi, kinerja auditor mempunyai pengaruh terhadap perilaku disfungsional audit (Chairunnisa et al, 2014; Hadi dan Nirwanasari, 2014; dan Pujaningrum, 2012).

Pengaruh Gaya Kepemimpinan Terhadap Perilaku Disfungsional Audit. Gaya kepemimpinan adalah pola perilaku konsisten yang diterapkan pemimpin dengan melalui orang lain, yaitu pola perilaku yang ditujukkan pemimpin pada saat memengaruhi orang lain. Gaya kepemimpinan merupakan perilaku pemimpin dalam dua dimensi yaitu consideration dan initiating structure. 
Hasil penelitian Outley dan Pierce (1996) yang menguji pengaruh gaya kepemimpinan terhadap perilaku audit disfungsional menunjukkan bahwa gaya kepemimpinan struktur inisiatif cenderung mengurangi perilaku audit disfungsional. Meskipun demikian, teori kontrol menyatakan bahwa dalam lingkungan audit, pengendalian yang kaku yang ditetapkan dalam sebuah organisasi akan mengurangi kecenderungan individu untul melakukan perilaku disfungsional audit. Jadi, gaya kepemimpinan mempunyai pengaruh terhadap perilaku disfungsional audit (Hadi dan Nirwanasari, 2014).

Pengaruh Komitmen Organisasi Terhadap Perilaku Disfungsional Audit. Komitmen organisasi merupakan sikap yang merefleksikan loyalitas karyawan pada organisasi sehingga anggota organisasi dapat mengekspresikan perhatiannya terhadap organisasi dan keberhasilan serta kemajuan yang berkelanjutan (Luthans, 2006:249). Komitmen organisasi menunjukkan kekuatan relatif untuk berpihak dan terlibat dalam organisasi, keinginan untuk berusaha sekuat tenaga untuk organisasi, termasuk juga keinginan untuk bertahan dalam organisasi merupakan orientasi individu terhadap organisasi dalam hal loyalitas, identifikasi dan keterlibatan. Dengan demikian, komitmen organisasi dengan perilaku disfungsional audit. Individu dengan komitmen organisasi yang tinggi akan memiliki keinginan agar organisasinya mencapai kesuksesan dan lebih memilih untuk menolak perilaku disfungsional audit (Chairunnisa et al, 2014).

\section{Pengaruh Locus of Control, Turnover Intention, Time Budget Pressure, Kinerja} Auditor, Gaya Kepemimpinan, Komitmen Organisasi Terhadap Perilaku Disfungsional Audit. Dalam penelitian ini, rangkaian yang terdapat dalam perilaku disfungsional audit adalah locus of control, turnover intention, time budget pressure, kinerja auditor, gaya kepemimpinan, komitmen organisasi. Individu yang memiliki locus of control internal cenderung tidak menerima perilaku disfungsional atas prosedur audit. Dan sebaliknya, individu yang memiliki locus of control eksternal biasanya memiliki kedudukan dibawah individu yang memiliki locus of control internal. Dan pada saat individu merasa bahwa kemampuannya tidak sesuai dengan tuntutan pekerjaan, maka individu tersebut cenderung melakukan perilaku disfungsional untuk mempertahankan kedudukannya. Auditor yang memiliki keinginan berpindah kerja lebih dapat terlibat dalam perilaku disfungsional karena menurunnya tingkat ketakutan yang ada dalam dirinya terhadap sanksi yang didapat bila perilaku tersebut dideteksi. Individu yang berniat meninggalkan pekerjaan, tidak begitu peduli dengan dampak buruk dari penyimpangan perilaku disfungsional audit terhadap penilai kerja dan promosi. Para auditor cenderung untuk memilih berusaha keras untuk mencapai anggaran yang ditetapkan daripada memilih profesionalisme kerja karena pentingnya pencapaian anggaran oleh seorang auditor dijadikan sebagai evaluasi kinerja mereka. Auditor terkadang melakukan ekploitasi beragam penyimpangan perilaku untuk mencapai anggran yang telah ditetapkan.

Adanya pandangan auditor bahwa evaluasi kinerja dan promosi karir dalam KAP sangat erat hubungannya dengan kemampuan untuk menuntaskan penugasan audit sesuai dengan waktu dan anggaran yang ada menuntut auditor supaya dapat melengkapi semua penugasan dan prosedur audit sebagai dasar dalam memberikan opini mengenai kewajaran laporan keuangan. Gaya kepemimpinan dengan struktur inisiatif cenderung mengurangi perilaku audit disfungsional. Individu dengan komitmen organisasi yang tinggi akan memiliki keinginan agar organisasinya mencapai kesuksesan. Oleh karena itu, individu tersebut akan lebih memilih untuk menolak perilaku disfungsional. Sebaliknya, individu 
dengan komitmen organisasi yang rendah akan memiliki keinginan untuk lebih berfokus pada kepentingan pribadi daripada kepentingan organisasi. Berdasarkan uraian di atas, maka rumusan hipotesis dan model kerangka pemikirannya adalah sebagaimana berikut:

H1: Locus of Control terhadap Perilaku Disfungsional Audit

H2: $\quad$ Turnover Intention terhadap Perilaku Disfungsional Audit

H3: $\quad$ Time Budget Pressure terhadap Perilaku Disfungsional Audit

H4: $\quad$ Kinerja Auditor terhadap Perilaku Disfungsional Audit

H5: Gaya Kepemimpinan terhadap Perilaku Disfungsional Audit

H6: Komitmen Organisasi terhadap Perilaku Disfungsional Audit

H7: Locus of Control, Turnover Intention, Time Budget Pressure, Kinerja Auditor, Gaya Kepemimpinan, dan Komitmen Organisasi terhadap Perilaku Disfungsional Audit

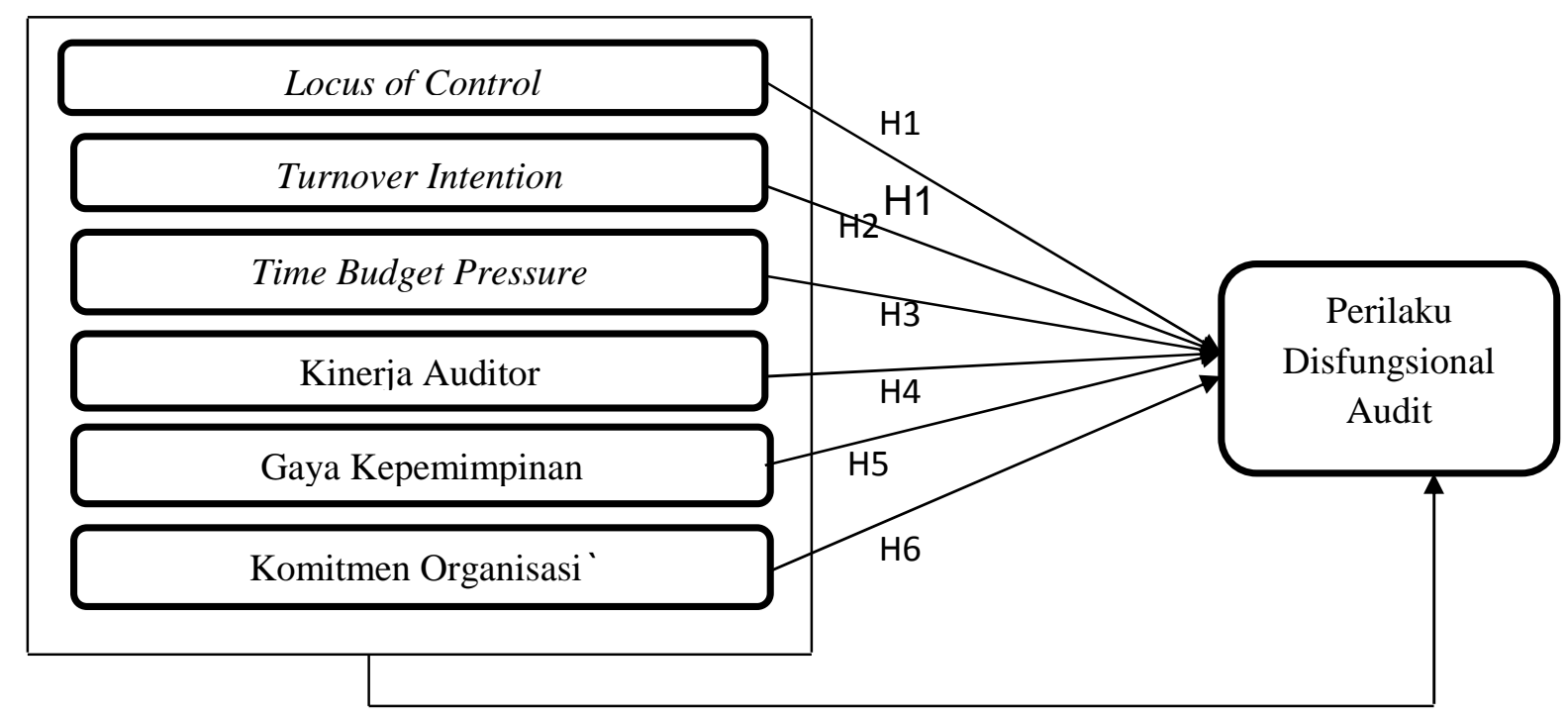

$\mathrm{H} 7$

Gambar 1. Kerangka Pemikiran

\section{METODE}

Populasi Dan Sampel. Populasi dalam penelitian ini adalah seluruh auditor yang bekerja di dalam Kantor Akuntan Publik (KAP) yang berlokasi di Jakarta. Menurut informasi yang diperoleh dari Institut Akuntan Publik Indonesia (IAPI) tahun 2013, jumlah KAP secara keseluruhan yang terdaftar dan berlokasi di Jakarta adalah 236 KAP. Sedangkan pengambilan sampel dalam penelitian ini menggunakan teknik purposive sampling yang pengambilan sampel dilakukan denga mengambil sampel dari populasi berdasarkan suatu kriteria tertentu (Hartono, 2012:96). Kriteria sampel yang diambil diantaranya adalah kantor akuntan publik yang terdaftar di Bursa Efek Indonesia, kantor akuntan publik yang memiliki rekan kerja lebih dari satu, umur kantor akuntan publik lebih dari 2-3 tahun.

Sampel yang memiliki kriteria diatas terdapat 32 Kantor Akuntan Publik di Jakarta. Berdasarkan sampel yang telah ditentukan maka kriteria responden dalam penelitian ini adalah pertama, telah bekerja sebagai auditor selama lebih dari satu tahun. Auditor yang 
telah bekerja minimal setahun diharapkan telah memahami hal- hal yang bersifat negatif dalam melaksanakan tugasnya sehingga dapat diketahui pengaruh hal- hal yang menyebabkan seorang auditor melakukan perilaku disfungsional, kedua memiliki latar belakang pendidikan minimal Strata Satu (S1) jurusan akuntansi. Auditor yang memiliki pendidikan minimal S1 akuntansi diharapkan memiliki pengalaman tertentu tentang kinerja auditor. Berdasarkan kriteria responden diatas maka jumlah responden dalam penelitian ini adalah 256 auditor yang bekerja Kantor Akuntan Publik di Jakarta.

Jenis Data Dan Teknik Pengumpulan Data. Dalam penulisan ini jenis data yang digunakan adalah data primer. Dalam penelitian ini, data primer diperoleh menggunakan teknik penyebaran kuesioner kepada para responden yakni auditor yang bekerja Kantor Akuntan Publik di Jakarta.

\section{Teknik Analisis Data}

Teknik analisis data yang digunakan dalam penelitian ini dilakukan dengan beberapa teknik berikut ini, yaitu: Pertama. Statistik Deskriptif. Statistik deskriptif adalah statistik yang dipakai untuk menganalisa data dengan cara mendeskripsikan atau menggambarkan data yang telah terkumpul sebagaimana adanya tanpa ada tujuan membuat kesimpulan untuk generalisasi. Statistik deskriptif yang digunakan dalam penelitian ini meliputi mean (rata-rata hitung), standar deviasi, dan range. Kedua. Uji Kualitas Data.

a. Uji Validitas Data. Uji validitas digunakan untuk mengukur sah atau tidaknya suatu kuisioner (Ghozali, 2011:54). Suatu kuesioner dikatakan valid jika pernyataan dalam kuesioner mengungkapkan sesuatu yang akan diukur oleh kuesioner tersebut. Jadi validitas ingin mengukur apakah pertanyaan dalam kuesioner yang sudah dibuat benarbenar dapat mengukur apa yang hendak diukur oleh peneliti. Dalam penelitian ini untuk mengukur validitas peneliti melakukan korelasi bivariate antara masing-masing skor indikator dengan total skor konstruk (construct). Jika korelasi antara masingmasing indikator terhadap total konstruk menunjukkan hasil yang signifikan yaitu $r$ hitung $>\mathrm{r}$ tabel, maka dapat disimpulkan bahwa masing-masing indikator pertanyaan dalam kuesioner adalah valid.

b. Uji Reliabilitas Data. Reliabilitas adalah alat untuk mengukur suatu kuesioner yang merupakan indikator dari variabel atau konstruk (Ghozali, 2011:47). Uji reliabilitas dilakukan untuk mengetahui sejauh mana butir-butir pertanyaan atau pernyataan dalam kuesioner yang diajukan dalam penelitian dapat dipercaya (handal). Jawaban responden terhadap pertanyaan dikatakan reliable jika masing-masing pertanyaan dijawab secara konsisten atau jawaban tidak boleh acak oleh karena masing-masing pertanyaan hendak mengukur hal yang sama. Untuk melakukan pengujian terhadap butir-butir pertanyaan, peneliti menggunakan Cronbach's Alpha $(\alpha)$. Menurut Nunnally (1994) dalam Ghozali (2011:47) suatu konstruk atau variabel dikatakan reliable jika memberikan nilai CronbachAlpha $>0.70$. Sebaliknya jika nilai Cronbach Alpha $<0.70$ maka instrumen penelitian dari konstruk tersebut tidak reliable.

Ketiga. Uji Normalitas Data. Sebelum melakukan uji statistik langkah awal yang harus dilakukan adalah screening terhadap data yang akan diolah untuk mengetahui normalitas datanya. Salah satu uji statistik yang dapat digunakan untuk tujuan itu adalah uji Kolmogorov-Smirnov. Pedoman pengambilan keputusan tentang data tersebut mendekati atau merupakan distribusi normal dapat dilihat dari : Nilai sign. Atau signifikan atau probabilitas $<0,05$ maka distribusi data adalah tidak normal. Demikian pula sebaliknya, 
jika nilai sign. Atau signifikan atau probabilitas > 0,05 maka distribusi data adalah normal (Ghozali, 2011:29).

Keempat. Uji Asumsi Klasik

a. Uji Normalitas Regresi. Uji normalitas dalam model regresi bertujuan menguji apakah variabel residual berdistribusi normal. Hal ini didukung oleh asumsi uji signifikan regresi parsial (uji t) dan uji signifikan regresi berganda(uji f) yaitu nilai residual mengikuti distribusi normal. Deteksi uji normalitas dalam model regresi dalam penelitian ini dilakukan dengan melihat penyebaran titik - titik pada sumbu diagonal dalam grafik Normal P-P Plot Regression Standardized dengan kriteria (1) Jika data menyebar disekitar garis diagonal dan mengikuti arah garis diagonal menunjukkan pola distribusi normal dan memenuhi asumsi normalitas, (2) Jika data menyebar jauh dari diagonal dan tidak mengikuti arah garis diagonal tidak menunjukkan pola distribusi normal dan tidak memenuhi asumsi normalitas (Ghozali, 2011:29).

b. Uji Multikoliniaritas. Uji multikolinieritas bertujuan untuk menguji apakah variable dalam model regresi ditemukan adanya korelasi antara variable bebas (independen). Model regresi yang baik seharusnya tidak terjadi korelasi diantara variable bebas. Untuk mendeteksi ada tidaknya multikolinieritas di dalam model regresi, digunakan (1) nilai tolerance dan (2) Variance Inflation Factor (VIF) dengan kriteria pengambilan keputusan suatu model regresi bebas multikolinieritas adalah sebagai berikut: (1) Mempunyai nilai VIF dibawah 10, (2) Mempunyai nilai tolerance diatas 0,10

c. Uji Heteroskedastisitas. Uji ini bertujuan untuk menguji apakah dalam model regresi terjadi ketidaksamaan variance dari satu residual pengamatan kepengamatan yang lain (Ghozali, 2011:139). Model regresi yang baik adalah tidak terjadi heteroskedastisitas. Salah satu cara untuk mendeteksi heteroskedastisitas adalah dengan melihat grafik scatterplot antara lain prediksi variable terikat (ZPREID) dengan residualnya (SRESID). Jika ada titik pola tertentu yang teratur (bergelombang, melebar kemudian menyempit) maka mengindikasikan telah terjadi heteroskedastisitas. Jika tidak ada pola yang jelas, serta titik-titik menyebar diatas dan dibawah angka 0 pada sumbu $Y$, maka tidak terjadi heteroskedastisitas (Ghozali, 2011).

Kelima. Pengujian Hipotesis

a. Uji Signifikansi Regresi parsial (uji Statistik T). Uji signifikansi regresi parsial atau uji statistik t pada dasarnya menunjukkan seberapa jauh pengaruh satu variabel bebas secara individual dalam menerangkan variasi variabel terikat. Adapun kriteria uji adalah jika $t_{0}>t_{\text {tabel }}$ : signifikan, maka $H_{0}$ ditolak, Ha diterima atau jika $t_{0}<t_{\text {tabel }}$ : tidak signifikan, maka $\mathrm{H}_{0}$ diterima, Ha ditolak.

b. Uji Signifikansi Regresi Berganda (Uji Statistik F). Uji signifikansi regresi berganda atau uji statistik F pada dasarnya menunjukkan apakah semua variabel bebas yang dimasukkan dalam model mempunyai pengaruh secara bersama-sama terhadap variabel terikat. Adapun kriteria Ujinya adalah: jika $\mathrm{F}_{\mathrm{o}}>\mathrm{F}_{\text {tabel }}$ : signifikan, maka $\mathrm{H}_{0}$ ditolak, Ha diterima atau jika $\mathrm{F}_{\mathrm{o}}<\mathrm{F}_{\text {tabel }}$ : tidak signifikan, maka $\mathrm{H}_{0}$ diterima, $\mathrm{Ha}$ ditolak.

c. Koefisien Determinasi. Koefisein determinasi $\left(\mathrm{R}^{2}\right)$ dapat dilihat pada nilai Adjusted $R$ Square yang menunjukkan seberapa besar variabel independent dapat menjelaskan variabel dependen. Semakin tinggi nilai Adjusted R Square maka berarti semakin baik model regresi yang digunakan. Karena menandakan bahwa kemampuan variabel bebas 
menjelaskan variabel terikat juga semakin besar, demikian sebaliknya. Nilai koefisien determinasi adalah $0 \leq \mathrm{R}^{2} \leq 1$. Kemampuan model dalam menerangkan variabel dependen semakin baik bila nila-nilai $\mathrm{R}^{2}$ semakin mendekati 1 (Ghozali, 2011:100).

\section{HASIL DAN PEMBAHASAN}

Kuesioner diserahkan kepada 32 KAP di Jakarta yang memenuhi kriteria dari populasi sebesar 256 KAP yang terdaftar dalam Institut Akuntan Publik Indonesia (IAPI). Penyebaran kuesioner dilakukan oleh peneliti kurang lebih selama 1 bulan. Untuk rincian demografi responden dalam penelitian ini dapat dijelaskan sebagai berikut: jenis kelamin pria yaitu sebesar $59,5 \%$ dan sisanya sebesar $40,5 \%$ berjenis kelamin wanita. Pendidikan responden sebagian besar adalah $\mathrm{S} 1$ yaitu sebesar 63,5\%, sedangkan sebesar 36,5\% adalah lulusan S2. Responden dengan lama bekerja 1-5 tahun adalah 53\%, sedangkan sisanya sebesar 37\% telah bekerja selama 6-10 tahun dan 10\% telah bekerja selama lebih dari 10 tahun. Responden yang memiliki posisi sebagai junior auditor sebesar 72,5\%, dan responden yang memiliki posisi sebagai senior auditor sebesar 17,5\%, sedangkan responden yang memiliki posisi sebagai manager sebesar $10 \%$. Dan menurut hasil dari data responden, yang memiliki usia 21-30 tahun sebesar 62,5\%, 31-40 tahun sebesar 25\% dan untuk usia 41-50 tahun sebesar 12,5\%.

Response Rate Kuesioner. Dalam Tabel 1 dapat dilihat bahwa jumlah kuesioner yang disebarkan adalah sebanyak 256 kuesioner dengan jumlah item pertanyaan sebanyak 60 butir. Dari 256 kuesioner yang disebarkan sebesar $88 \%$ atau sebanyak 200 kuesioner yang mendapat respon, sedangkan sisanya $22 \%$ atau sebanyak 56 kuesioner tidak mendapat respon

Tabel 1. Response Rate Kuesioner

\begin{tabular}{lcc}
\hline \multicolumn{1}{c}{ Keterangan } & Jumlah & Persentase \\
( orang ) & $(\%)$ \\
\hline Kuesioner yang disebar & 256 & 100 \\
Kuesioner yang tidak mendapat respon & 56 & 22 \\
Kuesioner yang mendapat respon & 200 & 88 \\
Kuesioner yang tidak sesuai dengan kriteria sampel & 0 & 0 \\
Kuesioner yang dapat diolah & 200 & 88 \\
\hline
\end{tabular}

Sumber: Data primer diolah, 2016

Analisis Data. Statistik deskriptif menunjukkan nilai rata-rata (mean), standar devisasi, dan range untuk masing-masing variabel dalam penelitian ini adalah sebagaimana dalam Tabel 2.

Pada Tabel 2, berdasarkan hasil statistik deskriptif disimpulkan bahwa: (1) Perilaku Disfungsional Audit mempunyai nilai mean (rata-rata) sebesar 31,48, nilai range sebesar 27 dan nilai standar deviasi sebesar 8,026, (2) Locus of Control mempunyai nilai mean (rata-rata) sebesar 45,91, nilai range sebesar 39 dan nilai standar deviasi sebesar 11,578, (3) Turnover Intetion mempunyai nilai mean (rata-rata) sebesar 17,69, nilai range sebesar 15 dan nilai standar deviasi sebesar 4,648, (4) Time Budget Pressure mempunyai nilai mean (rata-rata) sebesar 28,14, nilai range sebesar 24 dan nilai standar deviasi sebesar 7,325, (5) Kinerja Auditor mempunyai nilai mean (rata-rata) sebesar 24,59, nilai range sebesar 21 dan nilai standar deviasi sebesar 6,388, (6) Gaya Kepemimpinan mempunyai 
nilai mean (rata-rata) sebesar 32,07, nilai range sebesar 27 dan nilai standar deviasi sebesar 7,946, (7) Komitmen Organisasi mempunyai nilai mean (rata-rata) sebesar 32,01, nilai range sebesar 27 dan nilai standar deviasi sebesar 9,332

Tabel 2. Hasil Statistik Deskriptif

\begin{tabular}{ccccc}
\hline & N & Range & Mean & Std. Deviation \\
\hline PDA & 200 & 27 & 31.48 & 8.026 \\
LOC & 200 & 39 & 45.91 & 11.578 \\
TI & 200 & 15 & 17.69 & 4.648 \\
TBP & 200 & 24 & 28.14 & 7.325 \\
KA & 200 & 21 & 24.59 & 6.388 \\
GK & 200 & 27 & 32.07 & 7.946 \\
KO & 200 & 27 & 32.01 & 9.332 \\
Valid N (listwise) & 200 & & & \\
\hline
\end{tabular}

Sumber: SPSS Versi 23.0 for window

Uji Kualitas Data. Hasil Uji Validitas dan Reliabilitas. Hasil Uji Validitas menunjukkan bahwa semua pertanyaan dalam kuesioner yang sudah dibuat benar-benar dapat mengukur apa yang hendak diukur oleh peneliti karena seluruh item pertanyaan untuk perilaku disfungsional audit $(\mathrm{Y})$ memiliki nilai $r$ hitung $>r$ tabel yang berarti bahwa seluruh item pertanyaan untuk variabel perilaku disfungsional audit (Y) dinyatakan valid. Demikian pula dengan hasil uji reliabilitas, dimana nilai Cronbach Alpha > 0.70 (Nunnally, 1967 dalam Ghozali, 2006) atas semua pertanyaan dari variabel dependen dan independen teruji reliabilitasnya.

Uji Normalitas Data. Pedoman pengambilan keputusan tentang data tersebut mendekati atau merupakan distribusi normal dapat dilihat dari: (1) Nilai sign. atau signifikan atau probabilitas < 0,05 maka distribusi data adalah tidak normal, (2) Nilai sign. atau signifikan atau probabilitas > 0,05 maka distribusi data adalah normal, dan (3) Hasil Output perhitungan uji normalitas data menggunakan program SPSS versi 19.0 menunjukkan nilai hasil output One-Sample Kolmogorov-Smirnov Test dapat dilihat bahwa data kuesioner berdistribusi normal karena hasil Asymp. Sign variabel independen maupun dependen lebih besar dari 0,05 .

Uji Asumsi Klasik. Uji Normalitas Regresi. Dalam penelitian ini uji normalitas menggunakan grafik Normal P-P Plot Regression Standardized dengan kriteria: (1) Jika data menyebar disekitar garis diagonal dan mengikuti arah garis diagonal menunjukkan pola distribusi normal dan memenuhi asumsi normalitas, (2) Jika data menyebar jauh dari diagonal dan tidak mengikuti arah garis diagonal tidak menunjukkan pola distribusi normal dan tidak memenuhi asumsi normalitas. 


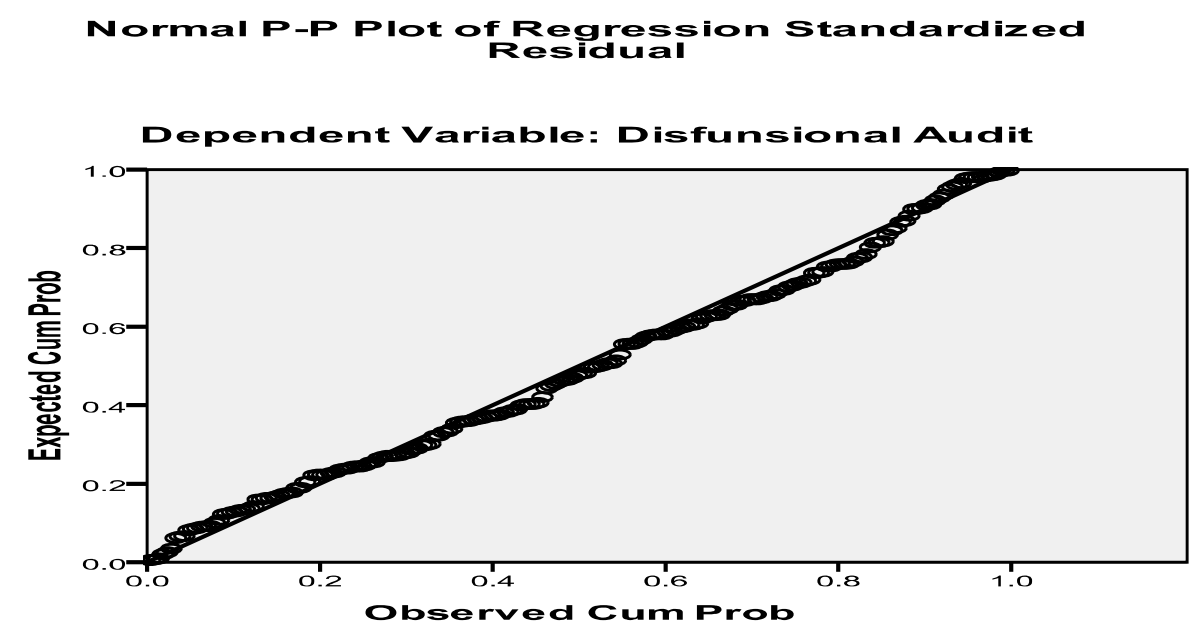

Gambar 1. Uji P Plot

Sumber: SPSS Versi 23.0 for window

Tampak dari Gambar 1 grafik normal plot dapat disimpulkan bahwa grafik normal plot terlihat titik-titik menyebar disekitar garis diagonal, serta penyebarannya mengikuti dan mendekati garis diagonal. Ini menunjukkan bahwa model regresi layak dipakai karena memenuhi asumsi normalitas.

Uji Multikolinearitas. Salah satu cara untuk mendeteksi adanya multikolinieritas yaitu berdasarkan VIF (Variance Inflation Factor) dan besaran tolenrance. Adapun hasil uji multikolinieritas menunjukkan hasil bahwa VIF untuk variabel independen yang berada dibawah 10 dan nilai tolerance variabel independen yang besaran tolerance > 0,1 , sehingga dapat disimpulkan bahwa tidak terdapat multikolinearitas antar variabel bebas.

Uji Heteroskedastisitas. Uji heterokedastisitas dalam penelitian ini menggunakan uji scatterplot. Hasil menunjukkan sebagaimana gambar di bawah ini:

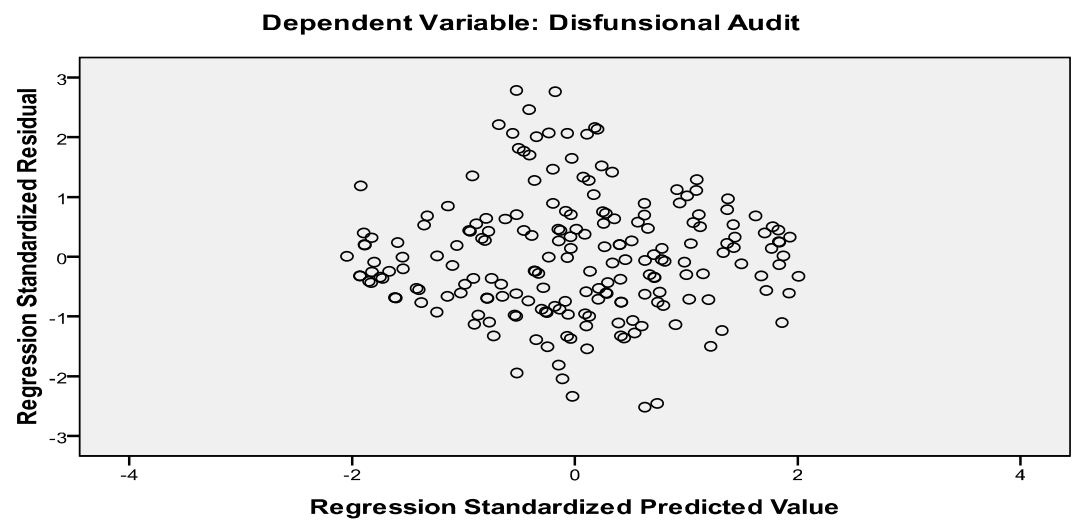

Gambar 2. Hasil Uji Scatterplot Sumber : SPSS Versi 23.0 for window

Berdasarkan grafik scatterplot di atas menujukkan tidak terjadi heteroskedastisitas karena penyebaran titik-titik menyebar secara acak serta tersebar dan tidak mempunyai pola 
tertentu sehingga dapat disimpulkan bahwa tidak terjadi heteroskedastisitas pada model regresi.

Uji Hipotesis. Tabel 3 merupakan hasil analisis regresi berganda yang diperoleh. Berdasarkan hasil tersebut selanjutnya akan dianalisis lebih dalam terkait dengan temuan penelitian sebagai mekanisme pembuktian hipotesis.

Tabel 3. Analisis Regresi Berganda

\begin{tabular}{|c|c|c|c|c|c|}
\hline \multirow[b]{2}{*}{ Model } & \multicolumn{2}{|c|}{$\begin{array}{l}\text { Unstandardized } \\
\text { Coefficients }\end{array}$} & \multirow{2}{*}{$\begin{array}{c}\text { Standardized } \\
\text { Coefficients }\end{array}$} & \multirow[b]{2}{*}{$\mathrm{T}$} & \multirow[b]{2}{*}{ Sig. } \\
\hline & $\mathrm{B}$ & Std. Error & & & \\
\hline 1(Constant) & 23.377 & 3.854 & & 6.066 & .000 \\
\hline LOC & -.132 & .048 & -.190 & -2.728 & .007 \\
\hline TI & .282 & .112 & .163 & 2.507 & .013 \\
\hline TBP & .471 & .062 & .430 & 7.592 & .000 \\
\hline $\mathrm{KA}$ & -.225 & .079 & -.179 & -2.863 & .005 \\
\hline GK & .023 & .055 & .022 & .406 & .685 \\
\hline $\mathrm{KO}$ & .023 & .043 & .027 & .534 & .594 \\
\hline
\end{tabular}

a. Dependent Variable: Disfunsional Audit

Sumber: SPSS Versi 23.0 for window

Berdasarkan hasil analisis regresi di atas, maka dapat disimpulkan bahwa locus of control, turnover intention, time budget pressure, kinerja auditor, gaya kepemimpinan, dan komitmen organisasi berpengaruh terhadap perilaku disfungsional audit karena nilai t tabel pada tingkat signifikan 0,05 dan df $1=198$ yang menunjukkan $\mathrm{t}$ hitung $>\mathrm{t}$ tabel. Dengan demikian hipotesis $\mathrm{H}_{1}-\mathrm{H}_{5}$ terbukti, kecuali hipotesis $\mathrm{H}_{6}$.

Tabel 4. Uji F

\begin{tabular}{llrrrrr}
\multicolumn{7}{c}{ ANOVA $^{\mathbf{b}}$} \\
Model & & Sum of Squares & Df & Mean Square & \multicolumn{1}{c}{ F } & \multicolumn{1}{c}{ Sig. } \\
\hline 1 & Regression & 7430.186 & 6 & 1238.364 & 44.345 & $.000^{\mathbf{a}}$ \\
& Residual & 5389.689 & 193 & 27.926 & & \\
& Total & 12819.875 & 199 & & & \\
\hline
\end{tabular}

a. Predictors: (Constant), Komitmen, Locus Of Control, Budget, Kepemimpinan, Kinerja, Turnover

b. Dependent Variable: Disfunsional Audit

Sumber: SPSS Versi 23.0 for window

Dengan melihat $\mathrm{F}$ tabel df1 $=6(\mathrm{k})$ dan df $2=193(\mathrm{n}-\mathrm{k}-1)$ dan pada nilai signifikan 0,05 maka diperoleh nilai $\mathrm{F}$ tabel sebesar 2,145801. Dengan diketahuinya Fo dan F tabel maka dapat disimpulkan bahwa $\mathrm{Fo}=44,345>\mathrm{F}$ tabel $=2$,145801. Berdasarkan hasil hipotesis tersebut, maka hipotesis ketujuh $\left(\mathrm{H}_{7}\right)$ diterima, berarti locus of control, turnover intention, time budget pressure, kinerja auditor, gaya kepemimpinan, dan komitmen organisasi $\left(\mathrm{X}_{6}\right)$ dengan perilaku disfungsional audit mempunyai pengaruh secara bersamasama. Dengan demikian hipotesis ketujuh $\left(\mathrm{H}_{7}\right)$ terbukti. 
Interpretasi Hasil Pengolahan Data Dan Pembahasan. Hipotesis H1 dalam penelitian ini diterima. Hasil penelitian ini sejalan dengan hasil penelitian yang dilakukan oleh (Chairunnisa, et al 2014). Tetapi hasil penelitian ini tidak sejalan dengan penelitian yang dilakukan oleh Gustati (2012). Hal ini disebabkan oleh auditor memiliki keyakinan terhadap kemampuannya sendiri sehingga melakukan tindakan menyimpang dalam audit untuk menyelesaikan tugasnya. Jadi, semakin tinggi locus of control eksternal seorang auditor, maka semakin kecil kemungkinan terjadinya perilaku menyimpang dalam audit. Individu yang memiliki locus of control internal cenderung tidak menerima perilaku disfungsional atas prosedur audit. Dan sebaliknya individu yang memiliki locus of control eksternal biasanya memiliki kedudukan dibawah individu yang memiliki locus of control internal (Hartati, 2012). Hal ini dikarenakan individu dengan locus of control eksternal kurang percaya akan kemampuan dirinya sendiri dalam melakukan suatu pekerjaan dan tidak bisa menentukan nasib baiknya sendiri. Dan pada saat individu merasa bahwa kemampuannya tidak sesuai dengan tuntutan pekerjaan, maka individu tersebut cenderung melakukan perilaku disfungsional untuk mempertahankan kedudukannya (Hartati, 2012).

Hipotesis $\mathrm{H} 2$ dalam penelitian ini diterima. Hasil penelitian ini sejalan dengan hasil penelitian yang dilakukan oleh (Chairunnisa, et al 2012). Tetapi hasil penelitian ini tidak sejalan dengan penelitian yang dilakukan oleh Hadi dan Nirwanasari (2014). Auditor yang memiliki keinginan berpindah kerja lebih dapat terlibat dalam perilaku disfungsional karena menurunnya tingkat ketakutan yang ada dalam dirinya terhadap sanksi yang didapat bila perilaku tersebut dideteksi. Individu yang berniat meninggalkan pekerjaan, tidak begitu peduli dengan dampak buruk dari penyimpangan perilaku terhadap penilaian kinerja dan promosi. Auditor yang memiliki turnover intention atau keinginan berpindah kerja tinggi dapat terlibat dalam perilaku menyimpang dalam audit karena menurunnya tingkat ketakutan yang ada dalam dirinya terhadap dijatuhkan sanksi apabila perilaku tersebut terdeteksi.

Hipotesis H3 dalam penelitian ini diterima. Hasil penelitian ini sejalan dengan hasil penelitian yang dilakukan oleh (Suprianto, 2009). Time budget yang sangat ketat akan mendorong auditor untuk mengurangi atau menghilangkan prosedur audit yang dipandang tidak penting. Perilaku tersebut dinamakan Premature sign-off. Sebagai bukti adalah banyak auditor yang dalam praktiknya tidak melaksanakan pengujian pengendalian intern (seperti hasil survey dengan auditor yang menyatakan bahwa jarang melakukan prosedur audit ini).

Hipotesis $\mathrm{H} 4$ dalam penelitian ini diterima. Hasil penelitian ini sejalan dengan hasil penelitian yang dilakukan oleh (Chairunnisa, et al 2012). Tetapi hasil penelitian ini tidak sejalan dengan penelitian yang dilakukan oleh Hadi dan Nirwanasari (2014). Auditor yang memiliki persepsi yang rendah terhadap tingkat kinerja mereka dianggap akan memperlihatkan penerimaan perilaku menyimpang dalam audit yang lebih tinggi (Irawati, 2005). Hal ini dikarenakan auditor dengan kinerja yang rendah akan merasa harus meningkatkan kinerja mereka dengan berbagai tindakan termasuk salah satunya perilaku menyimpang, seperti menghentikan satu atau beberapa prosedur audit tanpa menggantikan dengan langkah yang lain untuk mencapai waktu tugas yang ditetapkan oleh atasan. Hal ini menunjukkan bahwa auditor yang memiliki kinerja yang baik cenderung melakukan tugas dengan baik. Sedangkan auditor dengan tingkat kinerja dibawah harapan pimpinannya memiliki kemungkinan yang lebih besar terlibat perilaku menyimpang dalam 
audit karena menganggap dirinya tidak mempunyai kemampuan untuk bertahan dalam organisasi melalui usahanya sendiri.

Hipotesis H5 dalam penelitian ini ditolak. Hasil penelitian ini sejalan dengan hasil penelitian yang dilakukan oleh (Chairunnisa, et al 2014). Tetapi hasil penelitian ini tidak sejalan dengan penelitian yang dilakukan oleh Hadi dan Nirwanasari (2014). Gaya kepemimpinan yang merupakan cara pimpinan untuk memengaruhi orang lain atau bawahannya sedemikian rupa sehingga orang tersebut mau melakukan apa yang menjadi kehendaknya dalam mencapai tujuan organisasi meskipun secara pribadi mungkin ada halhal yang tidak disenangi. Jadi bawahan akan bekerja lebih baik bukan karena memiliki atasan atau pimpinan yang selalu mendefinisikan secara jelas tugas atau tanggung jawab dari masing-masing karyawan akan suatu pekerjaan tertentu yang mereka hadapi dan menjelaskan cara menyelesaikan pekerjaan tersebut.

Hipotesis H6 dalam penelitian ini ditolak. Hasil penelitian ini sejalan dengan hasil penelitian yang dilakukan oleh (Hadi dan Nirwanasari, 2014). Tetapi hasil penelitian ini tidak sejalan dengan penelitian yang dilakukan oleh Pujaningrum (2012). Kurangnya motivasi yang ada di dalam diri auditor untuk sama-sama menciptakan tujuan organisasi yang merupakan tujuan bersama dan menunjukkan bahwa komitmen organisasi bukan menjadi pertimbangan auditor dalam menerima perilaku menyimpang dalam audit. Dengan demikian teori Donelly et al (2003) yang menyatakan bahwa karyawan yang mempunyai komitmen lebih tinggi akan menunjukkan loyalitas yang besar kepada perusahaan dimana mereka bekerja dibandingkan karyawan yang memiliki komitmen yang lebih rendah, sehingga ada kecenderungan pula bahwa auditor yang memiliki komitmen yang tinggi pada KAP akan menerima saran-saran yang diberikan oleh atasan meskipun atasan dapat mendorong terjadinya perilaku menyimpang audit seperti misalnya premature sign off, maupun underreporting of time tidak terbukti.

$\mathrm{H}_{7}$ terbukti, hal tersebut ditunjukkan dengan nilai statistic $\mathrm{F}$ sebesar 44,345 dengan nilai signifikansi sebesar $0,000<0,05$ yang berarti locus of control, turnover intention, time budget pressure, kinerja auditor, gaya kepemimpinandan komitmen organisasi secara bersama-sama mempunyai pengaruh terhadap perilaku disfungsional audit. Nilai adjusted R-Square sebesar 0,580, artinya besarnya koefisien determinasi sebesar 0,580 hal ini menyatakan bahwa variabel independen menjelaskan variabel dependen sebesar $58 \%$. Sisanya $42 \%$ dipengaruhi oleh variable lain, seperti pengalaman. faktor situasional, dll.

\section{PENUTUP}

Simpulan. Dari hasil penelitian yang telah dilakukan, maka hasil yang di dapat bahwa Locus of Control, Turnover Intention, Time Budget Pressure, Kinerja Auditor mempunyai pengaruh terhadap perilaku disfungsional audit. Sedangkan Gaya Kepemimpinan dan Komitmen Organisasi tidak mempunyai pengaruh terhadap perilaku disfungsional audit. Secara simultan, locus of control, turnover intention, time budget pressure, kinerja auditor, gaya kepemimpinan dan komitmen organisasi mempunyai pengaruh terhadap perilaku disfungsional audit.

Keterbatasan. Penelitian ini masih memiliki beberapa keterbatasan antara lain bahwa penelitian menggunakan angket sehingga jawaban masing-masing responden dimungkinkan menjadi bias karena responden tidak membaca peryataan dengan benar dan bias menilai dirinya sendiri. Selain itu, variabel independen yang digunakan dalam 
penelitian ini hanya locus of control, turnover intention, time budget pressure, kinerja auditor, gaya kepemimpinan dan komitmen organisasi yang dinilai berpengaruh terhadap perilaku disfungsional audit. Selanjutnya, pemilihan sampel dan obyek dalam penelitian ini dibatasi kriteria tertentu yang ditetapkan peneliti.

Saran. Adapun saran yang diberikan kepada peneliti selanjutnya yang tertarik untuk melakukan penelitian mengenai perilaku disfungsional audit adalah penggunaan kombinasi metode pengumpulan data yang tidak hanya menggunakan kuesioner, namun juga menggunakan wawancara atau interaksi langsung dengan repsonden sehingga mampu mereduksi bias yang mungkin terjadi. Selain itu, peneliti lain juga dapat menambahkan atau mengganti variabel independen lain yang dinilai lebih relevan seperti pengalaman dan lain-lain sehingga hasil penelitian menjadi semakin baik dan semakin berkontribusi dalam pengembangan ilmu maupun praktis. Selanjutnya, peneliti dapat menambahkan kriteria yang lain untuk kantor akuntan publik sebagai tempat penelitiannya dan mengkombinasikan kriteria-kriteria lain untuk respondennya seperti frekusensi seorang auditor dalam menerima penugasan audit, dll.

\section{DAFTAR RUJUKAN}

Basuki dan Mahardani, K.Y. (2006) "Pengaruh Tekanan Anggaran Waktu terhadap Perilaku Disfungsional Auditor dan Kualitas Audit pada Kantor Akuntan Publik di Surabaya”. Jurnal Maksi, 6 (2), 203-221.

Chairunnisa, D., Zulbahridar dan Idrus, R. (2014) "Pengaruh Locus of Control, Komitmen Organisasi, Kinerja Auditor dan Turnover Intention terhadap Perilaku Menyimpang dalam Audit”. JOM FEKON, 1 (2) (Oktober), 1-16.

Christiawan, Y. J. (2003) "Kompetensi dan Independensi Akuntan Publik: Refleksi Hasil Penelitian Empiris". Jurnal Akuntansi dan Keuangan, 4 (2) (November), 79-92.

Coram, P., Glavovic, A., Ng, J dan Woodliff, D. (2004) "The Moral Intensity of Reduced Audit Quality Acts”. Auditing: A Journal of Practice and Theory, 27 (1) (May), 127149.

DeZoort, T dan Lord, Alan T. (1997) „A Review And Synthesis of Pressure Effects Research In Accounting". Journal of Accounting Literature, V16, University of South Carolina: 28-86.

Ghozali, I. (2011) Aplikasi Analisis Multivariate dengan Program IBM SPSS 19. Edisi V. Semarang: Badan Penerbit Universitas Diponegoro.

Gustati. (2012) "Persepsi Auditor tentang Pengaruh Locus of Control terhadap Penerimaan Perilaku Disfungsional Audit (Survey pada Auditor BPKP Perwakilan Provinsi Sumatera Barat)", Jurnal Akuntansi dan Manajemen, (7)2, 46-68.

Hadi, S dan Maghfiroh, N. (2014) "Pengaruh Karakteristik Personal dan Faktor Situasional Dalam Penerimaan Perlakuan Disfungsional". EKBISI, IX (1), (Desember), 15-24.

Harini, D., Wahyudin, A. dan Anisyakurillah I, (2010) Analisis Penerimaan Auditor Atas Dysfunctional Audit Behavior: Sebuah Pendekatan Karakteristik Personal Auditor, SNA XIII, Purwokerto.

Hartati, N.L. (2012) "Pengaruh Karakteristik Internal dan Eksternal Auditor terhadap Penerimaan Perilaku Disfungsional atas Prosedur Audit". Didownload dalam http://journal.unnes.ac.id/sju/index.php/aaj. 
Hartono, J. (2012) Metodologi Penelitian Bisnis, Edisi 5, Yogyakarta: BPFE.

Herningsih, S. (2001) "Penghentian Prematur Audit: Studi Empiris pada Akuntan Publik". Tesis. Universitas Gadjah Mada. Yogyakarta.

Irawati, Y., Petronila T.A. dan Mukhlasin. (2005) "Hubungan Karakteristik Personal Auditor Terhadap Tingkat Penerimaan Penyimpangan Perilaku Dalam Audit", Simposium Nasional Akuntansi VIII, Solo.

Kartika, I. danWijayanti, P. (2007) Locus of Control Sebagai Anteseden Hubungan Kinerja Karyawan dan Penerimaan Perilaku Disfungsional Audit. Simposium Nasional Akuntansi X, Makasar.

Kelley, T. dan Margheim, L. (1990) “The Impact of Time Budget Pressure, Personality, and Leadership Variables on Dysfunctional Auditor Behaviour". Auditing: A Journal of Practice and Theory, 9 (2), 21-42.

Lestari, AP. (2010) "Faktor-Faktor yang Memengaruhi Perilaku Auditor dalam Penghentian Prematur Prosedur Audit". Skripsi.Universitas Diponegoro, Semarang.

Luthans, F. (2006) Perilaku Organisasi, Edisi Sepuluh, Yogyakarta: Penerbit Andi.

Malone, C.F, dan R.W Robberts. (1996) "Factors Associated With The Incidence of Reduced Audit Quality Behaviors." Auditing: A Journal of Practice and Theory 15 (2), 49-644.

Mangkunegara, A. P., (2005) Evaluasi Kinerja SDM. Bandung: Refika Aditama.

Maryati, P. (2005) "Analisis Penerimaan Auditor atas Disfunctional Audit Behavior: Pendekatan Karakteristik Personal Auditor". Tesis. Universitas Diponegoro. Semarang.

Mulyadi dan Puradireja. (1998) Auditing. Jakarta: Salemba Empat. Buku 1. Edisi 5.

Hadi, S. dan Nirwanasari, M. (2014) "Pengaruh Karakteristik Personal dan Faktor Situasional dalam Penerimaan Perilaku Disfungsional”. EKBISI, IX (1), Desember: 15-24.

Otley D, Pierce J, (1996) "Auditor Time Budget Pressure: Consequences and Antecedents. Accounting", Auditing and Accountability Journal, 9 (1), 31-58.

Pujaningrum, I. (2012) “Analisis faktor-faktor yang memengaruhi tingkat penerimaan auditor atas penyimpangan perilaku dalam audit (Studi Empiris pada KAP di Semarang)". Jurnal Akuntansi, 1 (1), 1-15.

Robbins, S.P. (2008) Perilaku Organisasi. Edisi Bahasa Indonesia. Jakarta: PT INDEKS Kelompok GRAMEDIA.

Silaban, A. (2009) Perilaku Disfungsional Auditor Dalam Pelaksanaan Program Audit (Studi Empiris di KAP), Program Doktor Ilmu Ekonomi Universitas Diponegoro, Semarang.

Solar, D., dan D. Bruehl. (1971) "Machiavellianism and Locus of Control: Two Conceptions of Interpersonal Power”. Psychological Reports, 29 (3), 1079-1082

Soobaroyen, T dan Chelven, C. (2005) Auditors' Perception of Time Budget Pressure, Premature Sign Offs and Under-reporting of Chargeable, Time: Evidence from a Developing Country [On-line] http : //www.aber.ac.uk.

Sososutikno, C. (2005) Hubungan Tekanan Anggaran Waktu dengan Perilaku Disfungsional serta Pengaruhnya terhadap kualitas Audit, Simposium Nasional Akuntansi VI. Surabaya.

Suprianto, E. (2009) "Pengaruh Time Budget Pressure terhadap Perilaku Disfungsional Auditor". JAI, 5 (1), 57-65. 
Trisnaningsih, S. (2007) Indepedensi Auditor dan Komitmen Organisasi sebagai Mediasi Pengaruh Good Governance, Gaya Kepemimpinan dan Budaya Organisasi terhadap Kinerja Auditor. Simposium Akuntansi X, Makasar: 1-56.

Wibowo, A. E. (2010) "Pengaruh Kompetensi dan Independensi Auditor terhadap Kualitas Audit (Studi Empiris pada Kantor Akuntan Publik di Jawa Tengah)". Skripsi. Surakarta: UMS.

Wilopo. (2006) "Faktor-faktor yang Berpengaruh Terhadap Perilaku Disfungsional Auditor: Studi Pada KAP di Jawa Timur". Jurnal Akuntansi dan Teknologi Informasi, 5 (2), 141-152.

Winarto, E. (2002) Kartu Merah Buat 10 KAP Papan Atas. Media Akuntansi, Edisi 27, Juli-Agustus: 5. 